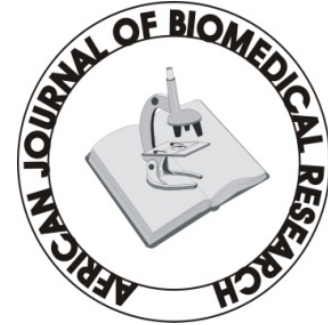

Full-text available at http://www.ajbrui.com http://www.bioline.br/md http://www.ajol.com

Received:

August 2007

Accepted (Revised):

November 2007

Published

January 2008
Full Length Research Article

\section{Some biochemical and haematological effects of black seed (Nigella sativa) oil on $T$. brucei-infected rats}

\author{
Justine T. EKANEM and Oluwatosin K. YUSUF \\ Trypanosomosis Research Unit, \\ Department of Biochemistry, University of Ilorin, \\ PMB 1515, Ilorin, Nigeria.
}

\section{ABSTRACT}

The effect of black seed oil (Nigella sativa oil) on parasitaemia, some serum and liver enzymes as well as some haematological parameters in Trypanosoma brucei-infected rats was investigated. The results show there was low parasitaemia and extension of life span of rats from 12 days of the infected untreated (control) rats to 22 days for the infected black seed oil-treated rats. Results also show significant increases in activities of serum alkaline phosphatase as well as glutamate oxaloacetate and glutamate pyruvate transaminases with decreases in the liver enzyme activities. Protein concentrations show significant decreases in the serum and increases in the liver. There were also significant increases in the haemoglobin $(\mathrm{Hb})$ concentration, packed cell volume (PCV), red blood cell (RBC), white blood cell (WBC) and platelet counts of infected oil-treated rats when compared with the infected untreated. We suggest that black seed oil has trypanocidal properties and probably stimulate the host immune system to control parasite proliferation thereby making it a possible agent for managing African sleeping sickness despite possible gradual damage to host organs as shown by increases in some serum enzymes.

(Afr. J. Biomed. Res. 11: 79 - 85)

Key Words; Black seed oil, T. brucei, sleeping sickness, management

*Address for Correspondence: jtekanem@scientist.com; toscue@yahoo.com 


\section{INTRODUCTION}

African trypanosomes cause trypanosomiasis, also known as sleeping sickness for which about 300,000 new cases are reported annually in some 36 developing African countries south of the Sahara where about 60 million people in some 200 locations are exposed to the risk of infection (Chretien and Smoak, 2005). Trypanosomiasis is fatal if left untreated and chemotherapy which forms the most important and major aspect of control and eradication of the disease in African countries is beset with problems of toxicity and increasing incidence of resistance among the trypanosomes to the existing drugs (Kioy \& Mattock, 2005; Moore, 2005). The search for new drugs and formulations that are safe, affordable and effective against both early and late stages of the disease is recommended (Jannin and Cattand, 2004; Chibale, 2005; Pink et al, 2005).

Parasitaemia correlates with the severity of infection (Anosa, 1988). The disease is further complicated by anaemia, thrombocytopaenia and leucopaenia (Davis, 1982; Suliman and Feldman, 1989; Biryomumaisho and KatungukaRwakishaya, 2007) all or some of which may be related to breakdown of the immune system and the observable pathological consequences of infection. Formulations or natural products which boost the host immune system and possibly reduce parasitaemia or completely remove parasites from the host system could contribute extensively to the control or management of the disease (Hoet et al, 2004; Chibale, 2005). We have earlier reported that the administration of honey to Trypanosoma brucei-infected rats was able to reduce the parasitaemia and extensively extend the life span of infected rats when compared with infected nontreated rats (Ekanem and Yusuf, 2005), even when included as part of the diet (Ekanem et al, 2006). Honey is a natural product reported to have immune-boosting properties (Abuharfeil, 1999).

The seed of black seed plant (Nigaella sativa) is known throughout the world with different names such as Seed of blessing (habbat-ul baraka), black cumin, black caraway, Kalonji etc. The black seed oil is reported to be beneficial due to its content of over a hundred components such as aromatic oils, trace elements, and vitamins (Ali \& Blunden, 2003). It is a phytotherapeutic known to reduce the risk to illness and disease by strengthening immune system and protecting the body (Hajhashemi et al, 2004; Tekeoglu et al, 2006). Recent reports however suggest that thymoquinone present in the oil might be the active component (Tekeoglu et al, 2006; Khattab and Nagi, 2007).

In this report, we assessed the trypanocidal properties of black seed oil, its potential as an immunoregulator in T. brucei-infected rats as well as its effect on some liver and serum enzymes as a way of determining its possible use in the control or management of African sleeping sickness.

\section{MATERIALS AND METHODS}

Federe strain of $T$. brucei was obtained from the Veterinary and Livestock Studies Department, Nigerian Institute for Trypanosomiasis Research, Vom, Plateau state, Nigeria. Black seed oil used for this work was a product of Iman International, United Kingdom purchased from around the University of Ilorin Central mosque, Ilorin, Nigeria.

Assay kits for glutamate oxaloacetate and glutamate pyruvate transaminases were products of Randox laboratories Ltd, United Kingdom and that of alkaline phosphatase was a product of Teco Ltd, United Kingdom.

\section{Inoculation of rats}

Parasite infested blood was obtained from the tail of infected rats at high parasitemia and used to maintain parasite suspension in $0.90 \%$ saline solution which was inoculated into the peritoneal cavity of uninfected rat weighing approximately 250g. The suspension as described earlier (Ekanem and Yusuf, 2005; Ekanem et al, 2006) contained 3 or 4 trypanosomes per view at x100 magnification (approximately $10^{6}$ cells per $\mathrm{ml}$ ).

\section{Parasite count}

Parasitaemia was determined by counting the number of trypanosomes per view under the light microscope at x100 magnification from thin blood 
smear obtained from the tip of the tail of infected rats.

\section{Administration of black seed oil}

Infected and uninfected rats were administered intraperitoneally with $0.5 \mathrm{ml}$ solution of black seed oil in distilled water containing $3.0 \mathrm{mg} / \mathrm{kg}$ body weight on the first day of sighting parasite in the blood (normally 3 days post infection) of infected rats. Administration of the black seed oil continued on daily basis until the infected rats died. Infected untreated rats were considered as the control against the infected oil-treated ones.

\section{Biochemical and haematological indices}

The biochemical and haematological determinations were carried out on the rats when the infections in the infected rats had progressed to the late stage of the disease (11 days). Serum and liver collection as well as alkaline phosphatase, glutamate pyruvate transaminase and glutamate oxaloacetate transaminase assays were carried out as earlier described (Ekanem and Yusuf, 2005; Ekanem et al, 2006).

Haemoglobin concentration (Hb), packed cell volume (PCV), red blood cell count (RBC), white blood cell count (WBC), mean cell haemoglobin concentration (MCHC) and platelet count were determined using the automated haematologic analyzer SYSMEX KX21, a product of SYSMEX Corporation, Japan employing the methods described by Dacie and Lewis, 1991.

Protein concentrations were determined using biuret method (Gornall et al, 1949) as described by Plummer, 1978.

\section{Statistical analysis}

Data were statistically analyzed and differences compared using the Student's ' $t$ ' test (Student, 1908) as described by Adamu and Johnson, 1997 while the level of statistical significance was taken at $5 \%$ confidence.

\section{RESULTS}

The parasitaemia of infected untreated group increased infinitely while infected oil-treated group shows a decrease in the proliferation (Fig 1). The treatment commenced the first day of sighting parasite in the bloodstream. The graph shows low replication of parasite and extension of life span of rats treated black seed oil from 12 days of the control (infected untreated) to 22 days for the infected-black seed oil treated rats.

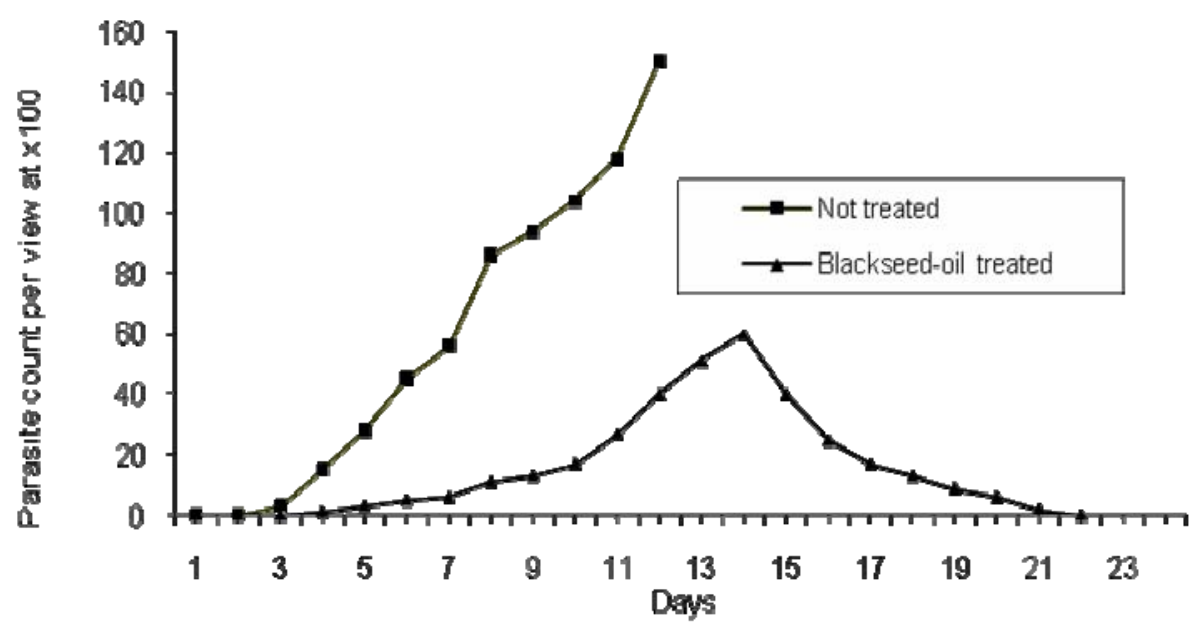

FIG 1: Parasite count of T. bruceininfected rats.Rats treated with honey and bleckseed oil were inoculated at $3.0 \mathrm{mg} / \mathrm{kg}$ body weight once daily until the arimals ded. Each point is an average cou int from five infexted rats 


\section{Protein concentrations}

There was significant decrease in serum protein concentration in the uninfected oil-treated and infected oil-treated rats in comparison with the infected untreated and uninfected (normal) rats. There was no significant difference in serum protein concentration in infected oil-treated, infected untreated and uninfected oil-treated rats when compared together. Significant increase was also observed when liver protein concentration in infected oil-treated rats were compared with infected untreated as well as with uninfected oiltreated rats (Table 1)

\section{Alkaline phosphatase activities}

Results of serum and liver alkaline phosphatase assays are shown in Table 2. At $\mathrm{p}<0.05$, serum alkaline phosphatase activities were significantly higher in infected untreated, uninfected oil-treated and infected oil-treated rats when compared with uninfected normal rats. The infected oil-treated rats also showed significantly high alkaline phosphatase activity in serum when compared with the serum activity in infected untreated rats. There was significant decrease in the liver enzyme activities in infected untreated, uninfected oiltreated and infected oil-treated rats when compared with the uninfected (normal) rats. The infected oil-treated values were also significantly lower than those of infected untreated rats.

\section{Glutamate oxaloacetate transaminase activities}

The serum Glutamate oxaloacetate transaminase activities show significant increases in the uninfected oil-treated, infected untreated and infected oil-treated rats when compared with the uninfected (normal) rats (Table 3). The liver glutamate oxaloacetate transaminase activities in the uninfected oil-treated, and infected oil-treated were significantly lower than that of the uninfected normal rats as well as infected untreated. The serum enzyme activity in the infected oil-treated was significantly higher than that of infected untreated rats while it was significantly lower in the liver.
Table 1: Protein concentrations in T. brucei infected rats at Day 11 post infection

\begin{tabular}{llc}
\hline Rat groupings & \multicolumn{1}{c}{$\begin{array}{c}\text { Protein concentration } \\
\text { (mg/ml) }\end{array}$} \\
\cline { 2 - 3 } & Serum & Liver \\
\hline Uninfected (normal) & $2.00 \pm 0.20$ & $0.400 \pm 0.00$ \\
\hline Infected Untreated & $1.07 \pm 0.47^{\mathrm{a}}$ & $0.467 \pm 0.18^{\mathrm{a}}$ \\
\hline Uninfected oil-treated & $1.20 \pm 0.44^{\mathrm{a}}$ & $0.488 \pm 0.17^{\mathrm{a}}$ \\
\hline Infected oil-treated & $1.15 \pm 0.51^{\mathrm{ab}}$ & $0.850 \pm 0.20^{\mathrm{ab}}$ \\
\hline $\begin{array}{l}\text { Each protein value is an average of five determinations } \\
\pm \text { SEM. Values are significantly different in comparison } \\
\text { with a uninfected (normal) rats and }{ }^{b} \text { infected untreated } \\
\text { rats at p < 0.05. }\end{array}$
\end{tabular}

Table 2:

Specific activities of alkaline phosphatase at Day 11 post infection

\begin{tabular}{lll}
\hline Rat groupings & \multicolumn{2}{l}{ Enzyme activity (IU/L) } \\
\cline { 2 - 3 } & Serum & Liver \\
\hline Uninfected (normal) & $31.95 \pm 2.00$ & $32.50 \pm 5.00$ \\
\hline Infected Untreated & $55.63 \pm 2.00^{\mathrm{a}}$ & $16.10 \pm 2.79^{\mathrm{a}}$ \\
\hline Uninfected oil-treated & $54.65 \pm 9.38^{\mathrm{a}}$ & $20.11 \pm 5.26^{\mathrm{a}}$ \\
\hline Infected oil-treated & $63.98 \pm 13.15^{\mathrm{ab}}$ & $9.47 \pm 2.82^{\mathrm{ab}}$ \\
\hline
\end{tabular}

Each specific enzyme activity is an average of five determinations \pm SEM. Values are significantly different in comparison with ${ }^{a}$ uninfected (normal) rats and ${ }^{b}$ infected untreated rats at $p<0.05$.

Table 3:

Specific activities of glutamate oxaloacetate transaminase at Day 11 post infection

\begin{tabular}{|c|c|c|}
\hline \multirow[t]{2}{*}{ Rat groupings } & \multicolumn{2}{|c|}{ Enzyme activity (IU/L) } \\
\hline & Serum & Liver \\
\hline Uninfected (normal) & $18.31 \pm 4.40$ & $90.00 \pm 10.50$ \\
\hline Infected Untreated & $27.35 \pm 5.77^{\mathrm{a}}$ & $86.67 \pm 13.90$ \\
\hline Uninfected oil-treated & $39.28 \pm 5.16^{\mathrm{a}}$ & $58.75 \pm 13.19^{\mathrm{ab}}$ \\
\hline Infected oil-treated & $37.09 \pm 4.89^{\mathrm{ab}}$ & $23.42 \pm 15.23^{\mathrm{ab}}$ \\
\hline
\end{tabular}


Table 4: Specific activities of glutamate pyruvate transaminase at Day 11 post infection

\begin{tabular}{|c|c|c|}
\hline \multirow[t]{2}{*}{ Rat groupings } & \multicolumn{2}{|c|}{ Enzyme activity (IU/L) } \\
\hline & Serum & Liver \\
\hline Uninfected (normal) & $20.39 \pm 1.30$ & $130.00 \pm 17.50$ \\
\hline Infected Untreated & $52.24 \pm 5.03^{\mathrm{a}}$ & $74.43 \pm 10.27^{\mathrm{a}}$ \\
\hline $\begin{array}{l}\text { Uninfected oil- } \\
\text { treated }\end{array}$ & $23.42 \pm 4.29$ & $150.00 \pm 17.25$ \\
\hline Infected oil-treated & $51.41 \pm 6.47^{\mathrm{ab}}$ & $43.45 \pm 11.01^{\mathrm{ab}}$ \\
\hline \multicolumn{3}{|c|}{$\begin{array}{l}\text { Each specific enzyme activity is an average of five } \\
\text { determinations } \pm \text { SEM. Values are significantly } \\
\text { different in comparison with }{ }^{a} \text { uninfected (normal) rats } \\
\text { and }{ }^{b} \text { infected untreated rats at } p<0.05 \text {. }\end{array}$} \\
\hline
\end{tabular}

\section{Glutamate pyruvate transaminase activities}

The results of the glutamate pyruvate transaminase activities in the serum and liver are presented in Table 4. The serum enzyme activities in the infected untreated and infected oil- treated rats are significantly higher than that of the uninfected normal and uninfected oil -treated rats. There was no significant difference in infected untreated and infected oil-treated rats. The liver glutamate pyruvate transaminase activity in the infected oiltreated rats was significantly lower than those of the normal and uninfected oil-treated rats, which were themselves comparable with each other.

\section{Haematological Indices}

The results of haematological studies are presented in Table 5. There were significant increases $(p<0.05)$ in the values of $\mathrm{Hb}, \mathrm{MCHC}, \mathrm{PCV}, \mathrm{RBC}$, WBC and platelet counts of the infected oil-treated rats in comparison with the infected untreated rats

\section{DISCUSSION}

Many studies have been carried out in recent years on the pharmacological effects of black seed oil (Hajhashemi et al, 2004; Tekeoglu et al, 2006).The oil has analgesic, antimicrobial, anti neoplastic, anti-inflammatory and immunological effects (Haq et al,1999; Hajhashemi et al, 2004; Salem, 2005; Tekeoglu et al, 2006). The seed and its oil are characterized by a very low degree of toxicity and have been shown not to induce significant adverse effects on liver functions (Ali and Blunden 2003). The oil of the closely related plant Nigella segetalis have been reported to increase haematocrit level but reduced MCHC and mean corpuscular volume (MCV) concentration (Kökdil, 2006).

Upon invasion of the mammalian system trypanosomes proliferate rapidly to establish its population in infected host (Poltera, 1985; Pentreath and Kennedy, 2004). Toxins are released into the mammalian system (Nwagwu et al, 1987; Boutignon et al, 1990; Ekanem, 1989; Ekanem et al, 1994, 1996). The antibodies produced by the host against the parasite are not effective because of the ability of the parasite to produce a large repertoire of antigens. The host defense mechanism is only partially specific and often lagging behind the progress of the disease in terms of antigen-antibody interaction (Sternberg, 2004).

Eventually there is a breakdown of the host immune system coupled with parasite invasion of the central nervous system leading to coma and death.

Table 5: Haematological indices of T. brucei - infected rats at 11 days post infection.

\begin{tabular}{|c|c|c|c|c|c|c|}
\hline $\begin{array}{c}\text { Rat } \\
\text { Groupings }\end{array}$ & $\mathrm{Hb}(\mathrm{g} / \mathrm{dl})$ & $\begin{array}{c}\text { MCHC } \\
\text { (g/dl) }\end{array}$ & PCV (\%) & $\begin{array}{c}\text { RBC } \\
\left(\mathrm{x} 10^{12} / \mathrm{L}\right) \\
\end{array}$ & $\begin{array}{c}\text { WBC } \\
\left(\mathrm{x} 10^{9} / \mathrm{L}\right) \\
\end{array}$ & Platelet $\left(\mathrm{x} 10^{9}\right)$ \\
\hline $\begin{array}{c}\text { Normal rats } \\
\text { uninfected }\end{array}$ & $12.95 \pm 1.45$ & $33.00 \pm 1.00$ & $39.50 \pm 3.50$ & $6.63 \pm 0.18$ & $16.80 \pm 3.20$ & $899.50 \pm 10.50$ \\
\hline $\begin{array}{c}\text { Infected } \\
\text { untreated }\end{array}$ & $7.20 \pm 0.00^{\mathrm{a}}$ & $24.00 \pm 0.50^{\mathrm{a}}$ & $30.00 \pm 0.50^{\mathrm{a}}$ & $3.99 \pm 0.70^{\mathrm{a}}$ & $7.20 \pm 1.14^{\mathrm{a}}$ & $319.67 \pm 89.59^{a}$ \\
\hline $\begin{array}{l}\text { Uninfected } \\
\text { oil-treated }\end{array}$ & $12.35 \pm 0.95$ & $34.50 \pm 0.50$ & $36.00 \pm 0.00$ & $6.08 \pm 0.41^{\mathrm{a}}$ & $16.55 \pm 3.95$ & $691.50 \pm 50.50^{\mathrm{ab}}$ \\
\hline $\begin{array}{c}\text { Infected } \\
\text { oil-treated }\end{array}$ & $10.80 \pm 0.40^{\mathrm{ab}}$ & $30.66 \pm 1.20^{b}$ & $38.67 \pm 2.60^{b}$ & $5.69 \pm 0.39^{b}$ & $12.07 \pm 1.55^{\mathrm{ab}}$ & $701.50 \pm 10.50^{\mathrm{ab}}$ \\
\hline
\end{tabular}


Removal of the parasite from the system and simultaneously boosting the host immune system could be very relevant in the control of African sleeping sickness (Hoet et al, 2004; Chibale, 2005).

Black seed oil has trypanocidal properties as well as the ability to extend the life span of $T$. brucei-infected rats (Fig 1). Despite the removal of the parasites from the blood, the infected rats still died by Day 23 suggesting the involvement of agents that are not necessarily life parasites. Factors extracellularly derived from the parasites (Nwagwu et al, 1987; Ekanem, 1989; Boutignon et al, 1990; Ekanem et al, 1994, 1996) could be responsible for the death.

The increase in protein concentration in the infected treated rats when compared with the infected untreated rats (Table 1) is an indication of increase in protein synthesis that may include those of antibodies and enzymes probably as a result of oil treatment as also observed in the uninfected oil treated rats in comparison with the uninfected (normal) untreated rats.

The activities of serum alkaline phosphatase, Glutamate oxaloacetate transaminase and glutamate pyruvate transaminase ordinarily are increased in the infected untreated rats when compared with those of the normal untreated rats (Tables 2, 3, and 4). This suggests and probably confirms earlier results (Ekanem and Yusuf, 2005; Ekanem et al, 2006) that infection could lead to gradual tissue especially liver destruction as decreases in the liver enzyme activities are also observed. Treatment with black seed oil however enhanced the situation as observed in the further increases in the activities of alkaline phosphatase and Glutamate oxaloacetate transaminase (Tables 2 and 3). There however was no significant difference in serum glutamate pyruvate transaminase activity (Table 4) in the infected oil treated rats in comparison with the infected untreated despite the decreases in the liver enzymes. The reasons for this discrepancy cannot be immediately determined but suppression of the glutamate pyruvate transaminase activity could be considered.

Measurement of anaemia gives an indication of severity of the disease (Poltera, 1985; Anosa,
1988; Suliman and Feldman, 1989; Pentreath and Kenedy, 2004). The increases in PCV and MCHC (Table 5) observed for infected oil treated rats in comparison with infected untreated suggest that black seed oil reduces the severity of $T$. brucei infection in rats. The observed increases in $\mathrm{Hb}$ and RBC concentrations are probably as a result of reduced severity of the infection and possible increase in the synthesis of the protein in line with observations in Table 1. The increased WBC and platelet counts (Table 5) are also indicative of the increased host action in the presence of black seed oil against the infection as these will contribute to the development of phagocytes and antibodies against the recognizable antigens of parasite origin.

The results suggest that black seed oil probably has trypanocidal properties as well as the ability to reduce parasitaemia and the severity of the disease. Immunodulation is probably one of the ways by which the oil achieves the results (Salem, 2005). Thymoquinone, the recently implicated active component of black seed oil (Tekeoglu et al, 2006; Khattab and Nagi, 2007) might be the cytotoxic constituent conferring trypanocidal properties on the oil. We are currently exploring this possibility along with the possibility of inactivating possible toxins extracellularly released by trypanosomes. We however suggest at this point that black seed oil could be a useful cheap agent for the management of African sleeping sickness as its benefits outweigh any possible side effects it may possess.

\section{REFERENCES}

Abuharfeil N, AlOran R, Aboshehada M (1999). The effect of bee honey on the proliferative activity of humab B- and T- lymphocytes and the activity of phagocytes. Food \& Agric. Immunol. 11: 169-177

Adamu SO, Johnson TL (1997) Statistics for beginners, Book 1. SAAL Publications, Ibadan, Nigeria. pp184-199

Ali BH, Blunden G (2003) Pharmacological and toxicological properties of Nigella sativa. Phytother. Res. 17(4): 299 - 305

Anosa VO (1988) Haematological and biochemical changes in human and animal trypanosomiasis. Revue Elev. Med. Vet. pays Trop 41 (42): 151 -164.

Biryomumaisho S, Katunguka-Rwakishaya E (2007) The pathogenesis of anaemia in goats experimentally 
infected with Trypanosoma congolense or Trypanosoma brucei: Use of the myeloid:erythroid ratio. Vet. Parasitol. 143: 354-357

Boutignon F, Huet G, Demeyer D, Richet C, Degand P (1990) Study of proteolytic activities released by incubation of trypanosomes (Trypanosoma brucei brucei). Biochim. Biophys. Acta 1035: 369-377

Chibale K (2005) Economic drug discovery and rational medicinal chemistry for tropical diseases. Pure \& Appl. Chem. 77: 1957-1964

Chretien J-PL, Smoak BL (2005) African Trypanosomiasis: Changing epidemiology and consequences. Curr. Infec. Dis. Reports 7: 54-60

Dacie JV, Lewis SM (1991) Practical Haematology, $7^{\text {th }}$ edn. Churchill Livingston. Edingburgh

Davis CE (1982) Thrombocytopenia: a uniform complication of African trypanosomiasis. Acta trop. 39: $123-133$

Ekanem JT (1989) Extracellular fractions derived from Trypanosoma brucei activate erythrocyte $\mathrm{Ca}^{2+}$ ATPase. Med. Sci. Res. 17:739-740.

Ekanem JT, Akanji MA, Odutuga AA (1994) Host and parasite derived factors during mammalian African trypanosomiasis. Biokemistri 4:103-116

Ekanem JT, Akanji MA, Odutuga AA (1996) Extracellular proteins of Trypanosoma brucei origin lyse erythrocytes of rats in vitro. Biokemstri. 6: 21-29.

Ekanem JT, Majolagbe OR, Sulaiman FA, Muhammad NO (2006) Effects of honeysupplemented diet on the parasitemia and some enzymes of Trypanosoma brucei-infected rats. Afr. J. Biotech. 5:1557-1561

Ekanem JT, Yusuf OK (2005) Activities of alkaline phosphatase, glutamate oxaloacetate transaminase and glutamate pyruvate transaminase in liver and serum of Trypanosoma brucei-infected rats treated with honey. Biokemistri 17:185-191

Gornall AG, Bardawill CJ, David MM (1949) Determination of Serum protein by means of the biuret reaction. J. Biol. Chem. 177: 751 - 756.

Hajhashemi V, Ghannadi A, Jafarabadi H (2004) Black cumin seed essential oil, as a potent analgesic and antiinflammatory drug. Phytother. Res. 18 (3): 195 $-199$

Haq A, Lobo PI, Al-Tufail M, Rama NR and AlSedairy ST (1999) Immunomodulatory effect of Nigella sativa proteins fractionated by ion exchange chromatography. Int. J. Immunopharmacol. 21(4):28395

Hoet S, Opperdoes F, Brun R, Quetin-Leclercq J (2004) Natural products active against African trypanosomes: a step towards new drugs. Nat. Product Reports 21: 353-364
Jannin J, Cattand P (2004) Treatment and control of human African trypanosomiasis. Curr.Op. Infec. Disease 17: 565-571

Khattab MM, Nagi MN (2007) Thymoquinone supplementation attenuates hypertension and renal damage in nitric oxide deficient hypertensive rats. Phytother. Res. (Articles online in advance of print) Published online: 18 Jan 2007. DOI: 10.1002/ptr.2083

Kioy D, Mattock N (2005) Control of sleeping sickness - time to integrate approaches. Lancet 366 (9487): 695-696

Kökdil G, Tamer L, Ercan B, Çelik M, Atik U (2006) Effects of Nigella orientalis and $N$. segetalis fixed oils on blood biochemistry in rats. Phytother. Res. 20(1): $71-75$

Moore AC (2005) Prospects for improving African trypanosomiasis chemotherapy. J. Infec. Dis. 191:17931795

Nwagwu M, Okenu DMN, Olusi TA, Molokwu RI (1987) Trypanosoma brucei releases proteases extracellularly. Trans. Roy. Soc. Trop. Med. Hyg. 82:577

Pentreath VW, Kennedy GE (2004) Pathogenesis of human African trypanosomiasis. In The Trypanosomiasis (eds. I. Maudlin, P. H. Holmes and Miles) CABI Publishing, pp 283-301

Pink R, Hudson A, Mouries M-A, Bendig M (2005) Opportunities and challenges in antiparasitic drug discovery. Nature Rev. Drug Discovery 49:727-740

Plummer $T$ (1978) An introduction to practical biochemistry ( $2^{\text {nd }}$ ed.) McGraw-HILL, London.pp144145

Poltera AA (1985) Pathology of human African trypanosomiasis with reference to experimental African trypanosomiasis and infections of the central nervous system. Brit. Med. Bull. 41:169-174

Salem ML (2005) Immunomodulatory and therapeutic properties of the Nigella sativa L. seed. Int. Immunopharmacol. 5(13-14):1749-70

Sternberg JM (2004) Human African trypanosomiasis: clinical presentation and immune response. Parasite Immunol. 26:469-476

Student, pseudo. (Gosset WS) (1908) The error of a mean. Biometrika 6: 1-25

Suliman HB, Feldman BF (1989) Pathogenesis and aetiology of anaemia in trypanosomiasis with special reference to T. brucei and T. evansi. Protozool. Abtr. 13:37-45

Tekeoglu I, Dogan A, Demiralp L (2006) Effects of thymoquinone (volatile oil of black cumin) on rheumatoid arthritis in rat models. Phytother. Res. 20 (10): $869-871$ 